\title{
A Cross Comparative Analysis of the German, Italian and American Healthcare Systems
}

By James Hennes, Franziska Kieselbach, Robin Klädtke, Katharine Wirsching, Roberta Zucchinali

\begin{abstract}
This chapter is a comparison between the German, Italian, and American Healthcare Systems. All three systems are designed to be redistributive and help needy populations receive healthcare, but the American system is ineffective because it does not cover vast portions of the population. In Italy, the policy problem lies in that the local governments have too much power over funding the system, which creates a problem with lack of oversight and a problem with efficiency. In Germany the healthcare system does provide universal healthcare, but this universality may threaten the system's future due to large demographic shifts. The final section of the paper will look at healthcare policy from a global perspective and future global policy recommendations.
\end{abstract}

Katharine Wirsching

E-mail: katharine.wirsching @wiwi.uni-augsburg.de

The final publication is available at:

https://link.springer.com/chapter/10.1007/978-3-319-17692-5_6 


\section{Literature Review}

The purpose of this literature review is to establish the significance of previous authors research on the topics of healthcare and healthcare reform. The majority of this section will look at different researchers work on the German, U.S., and Italian healthcare systems, their methodologies and ways to approach solving healthcare problems in each respective system.

The problems of the German health care system are serious. The authors Porter and Guth (2012) point out that the main source for the problem of the system are the rising costs of healthcare. The reason for that, are the ageing population and the decreasing working class as well as the rising demand for high technological medical treatment. They explain, that it is important to make the German healthcare system value - based regarding the patient value. The professors Greß and Rothgang also see a problem in the financing of the German system as they assume that the members of the statutory health system will not be able to pay for it in the future. The solution in their opinion is a package of measures such as the additional taxation of other incomes when charging premiums, the increase of limit for assessment of contribution, the reinforcement of the competition between the PHI and the SHI and the stronger tax financing of the system by the government. Other authors, such as Clarke und Bidgood (2013) rather see Germany as a role model for other countries like the UK. They point out the main characteristics of the Germany healthcare system which is very useful for understanding why reforms that aim for more justice in the social distribution can be implemented in Germany. Lauterbach (2004) wrote a paper about the so-called "Bürgerversicherung" which might be a possible solution for the German healthcare system in the future, as it suggests to integrate the private healthcare system into the statutory healthcare system.

For the U.S. healthcare system a major critique that has been pointed out is the fact that not everyone can receive or afford healthcare and it has created many problems in the society. Diggs pointed out that there has been a longstanding problem with groups or individuals to access healthcare in the United States and one of the reasons why lies in discrimination amongst certain races/ethnicities, orientation, class, or socio-economic statuses (Diggs 2012). Digg's main argument is that when talking about healthcare accessibility in the U.S. more needs to be focused on these types of discrimination. Diggs states that if these forms of discrimination are not addressed by policy makers the U.S. healthcare system will continue to fail its citizens (Diggs 2012).

Iglehart's research has a similar critique of the U.S. system and goes on to further critique the U.S. healthcare system stating that while the U.S. pays the most healthcare than any other country it still leaves a large number of the population without healthcare access (Iglehart 1999). Iglehart states that the U.S. system is still a work in progress and is in urgent need of reform especially in terms of healthcare access. Iglehart's main focus of his analysis on U.S. healthcare is through finances and government expenditures. Iglehart makes a point that the 
U.S. government expenditure of healthcare in increasing and will eventually become unsustainable. Iglehart goes on to state that despite the U.S.'s belief in free markets and capitalism the government still needs to be heavily involved in healthcare (Iglehart 1999).

Alesina et al's research is comparison between the European and American healthcare systems. The main focus of this paper is to do a cross-national perspective on why the U.S. system is different than the European approach (Alesina et al 2001). Their article mostly points to the racial heterogeneity in the U.S. amongst its institutions for the main difference. The article points out that the problem with the U.S. system might lie in racial animosity that affects redistribution of resources amongst the poor at a major reason for a lack of universal healthcare. Overall, Digg's, Iglehart's, Alesina's research were important to this paper because it helped shaped the major issues that the American system was facing and ways to look at solving the policy issue. They all mentioned that the U.S. healthcare system is vastly unequal and that major issues may lie in discrimination of certain minority populations in the U.S.

The Italian health care system is mainly structured on three-tiered levels divided between the central government, regions, and then finally local health authorities as it is clearly stated by G. France and L. Frisina Doetter. Their works focus also on the historical background and development of the Italian health care system which have led to a situation of misspending and overspending as it clearly stated by G. France. Other major issues of the system due to the current legislation regard mainly the funds misusage as political tool as explained by the Joint report on Health system elaborated by the European Commission; the increasing of the costs and the budget overtaking as explained by David Marris; the few subsidization provided by the government to the family who takes care of the elderly as described in A. Rusconi's paper; the great inequalities between the northern and southern Italian regions as argued by G. France.

\section{Introduction to the Policy and Value Comparison}

When talking about comparing cross-national healthcare it is important to notice that each nation bases its healthcare policies off of varying national priorities. The U.S. for instance, places a value on low taxes, low government expenditure, and marketization of most economic sectors. Germany and Italy, on the other hand, place a stronger value on social welfare. Because of these priorities there is no universal best system, each system depends on the unique characteristics of each state. Every country needs to be analyzed separately before they can be compared and unifying themes and overarching healthcare policies can be addressed. This paper will first analyze each of the three countries, Germany, the U.S., and Italy's healthcare models, conclude with individual policy recommendations, and then turn to healthcare policy in a global world. 


\section{The history of health care systems - four basic models}

In order to understand different healthcare systems across the world it is important to first understand the types of healthcare systems that already exist as most countries are influenced by these models. There are four basic models, the Bismarck model, the Beveridge model, the National Health Insurance (single player system) model, and the out-of-pocket model. The models will be explained more in depth below.

\subsection{The Bismarck Model}

The Bismarck model or, the German model, is arguably the most important healthcare model today. This is because Germany has the oldest universal health care system of the world and therefore has been an example for many other countries such as France, Belgium, Switzerland, Netherlands, etc. when establishing their own health care systems (Reid 2009). Before the development of the universal health care system, sickness funds existed in Germany which gave their members the possibility to regularly pay a certain amount to them so they were helped by the funds in times of illness (Radich 1995). After the unification of Germany in the year 1871, the German health care system has been established by the German Chancellor Otto von Bismarck within the Health Insurance Act in the year 1883 after he told Emperor Wilhelm I to recommend it in his Imperial Message in 1881 ("Kaiserliche Botschaft"). The message stated that the Reichstag should consider development of welfare in order to decrease the social damage which was caused by the industrialization (Obermann, Müller, Schmidt, Glazinsiki 2013). Bismarck was under great political pressure because he had to stop social riots in order to maintain German economic growth and efficiency during this time (Social Security Administration). The laws introduced within the Health Insurance Act forced all workers that did not earn more than 2000 RM (Reichsmark) to become a member of the public health system. Bismarck decided to build up a wage-dependent system where two-thirds of the contribution had to be paid by the workers themselves and one third was contributed by their employers. The coverage included a maximum of 13 weeks of illness, providence of medicine within these weeks, free choice of doctor and in case of inability to work they would receive 50 percent of their original wage (Bundesministerium für Arbeit und Soziales, 2014).

On this basis the "Bismarck Model" became the first health care system that was developed. As mentioned earlier other countries started to adopt the so-called "Bismarck Model" and also established universal health care systems. The main characteristics that these systems have in common are that hospitals as well as doctors and insurance providers, called "sickness funds", do not belong to the state but are private entities. Although independent from the state, the system is strongly influenced by the government as firstly the insurance companies are forced to 
accept every applicant and secondly everyone is forced to enter into an insurance provider. The health care system is financed by the insured employees and their employers and the insurance companies run on a non-profit basis (Reich 2009).

\subsection{The Beveridge Model}

The Beveridge Model of health care systems started to develop when Beveridge, a British economist and social reformer, was asked for advice when it came to rebuilding Great Britain after World War 2. In the famous "Beveridge Report" of the year 1942 he introduced a model of a welfare state to the government which then was implemented step by step under the prime minister Clement Attlee from 1945 on. In 1948 within the National Health Act, the first National Health Service which provided free medical services for the whole population (BBC 2014). The main characteristics for this model are that health insurance is financed by the government through taxes so it has a great control over the system. Furthermore, most hospitals are owned by the state and a lot of doctors are government employees - those who are not are at least paid trough taxes as well. The "Beveridge Model" has also been an example for other countries like Cuba, New Zealand, Spain, etc. (Reich 2009). As our later explanation of the Italian health care system will show, it rather fits into the "Beveridge Model" so Italy can be seen as an example for this model.

\subsection{The National Health Insurance Model}

Another health care system that must be mentioned in this context is the "National Health Insurance Model" which combines the Bismarck and the Beveridge model. Usually hospitals, doctors and insurance providers are private entities but they are financed through governmental insurance programs in which citizens pay either taxes or premiums. Derivatives of this model can be found in Canada, Taiwan and South Korea (Wallace 2013).

\subsection{The Out-Of-Pocket-Model}

The out-of-pocket-model actually is the most widespread health care model of the world as it basically exists in every country that is too poor or to unorganized to provide a health care system, such as rural regions of Africa, India, China, etc. . In case people need medical treatment and theoretically have access to it, they have to cover their doctor bill by themselves if they are able to. If they are not, they will not have the chance to receive medical service at all (Wallace 2013). 


\section{The German, the American and the Italian Healthcare Systems}

\subsection{The German Health Care System}

After the introduction of Bismarck's universal health care system, more and more workers were required to enter into Germany's health care system. Finally, in 2007 health care insurance became compulsory for every inhabitant of Germany such that only $0.2 \%$ of the population are uninsured today (Statistisches Bundesamt Pressequelle 2013).

The German health care system consists of a statutory health insurance (SHI) sector as well as of a private health insurance (PHI) sector. In $201186 \%$ of Germans were insured within the SHI system whereas the rest was privately insured (Statistisches Bundesamt Pressequelle 2013). The SHI is characterized by the sliding-scale principle which means, that every insured person has to pay a contribution depending on their wage and receives services depending on their needs of medical care so that the health care system has redistributive properties. In other words, the healthy ones pay for the sick and within that the wealthier ones help the poor (Bundeszentrale für politische Bildung). The size of contribution rate is presently $15.5 \%$ which is regulated by law ( $§ 241$ SGB V) (Bundesministerium für Gesundheit 2014) and it is split up between employee and employer. The employee's dependents are co-insured with him. The contribution rate is paid to the "illness funds" (insurance providers) monthly. In 2010 there were 169 competing public illness funds and the employee has the right to choose which one he wants to be insured through (Porter, Guth 2012). Those who earn more than 4,462.50 euros per month (or 53,550.00 euros per year) have the possibility to switch from the SHI into the PHI on a voluntary basis. Public officials and freelancers are usually also privately insured.

There were 46 private insurance providers in Germany in 2010 that cover premiums depending on the health risk of their members - those who are expected to be in need of a high quantity of medical services have to pay high contribution rates. As a consequence, the premiums that a member has to pay increase with their age so that members have the option to build up age reserves (capital reserves) at the provider during their insurance time (Porter, Guth 2012).

\subsubsection{Analysis of the German Healthcare System}

The quality of the German health care system in an international comparison has been decreasing over the last few years as the EHCI rankings of the years 2009 and 2012 show. In 2009, Germany ranked $6^{\text {th }}$ out of 34 different European coun- 
tries whereas in 2012 it was only ranked in $14^{\text {th }}$ place (Health Consumer Powerhouse 2012). Although these rank changes are quite alarming there are other factors that need to be taken into consideration.

As explained earlier, the German health care system is largely being financed by its labor force and their employers which is going to cause heavy financial problems for the system in the future. One factor that has a strong influence on this is that the population in Germany has been declining for years and still keeps on declining so that the labor force decreases -and with it the premiums being paid into the national health insurance (Porter, Guth 2012).

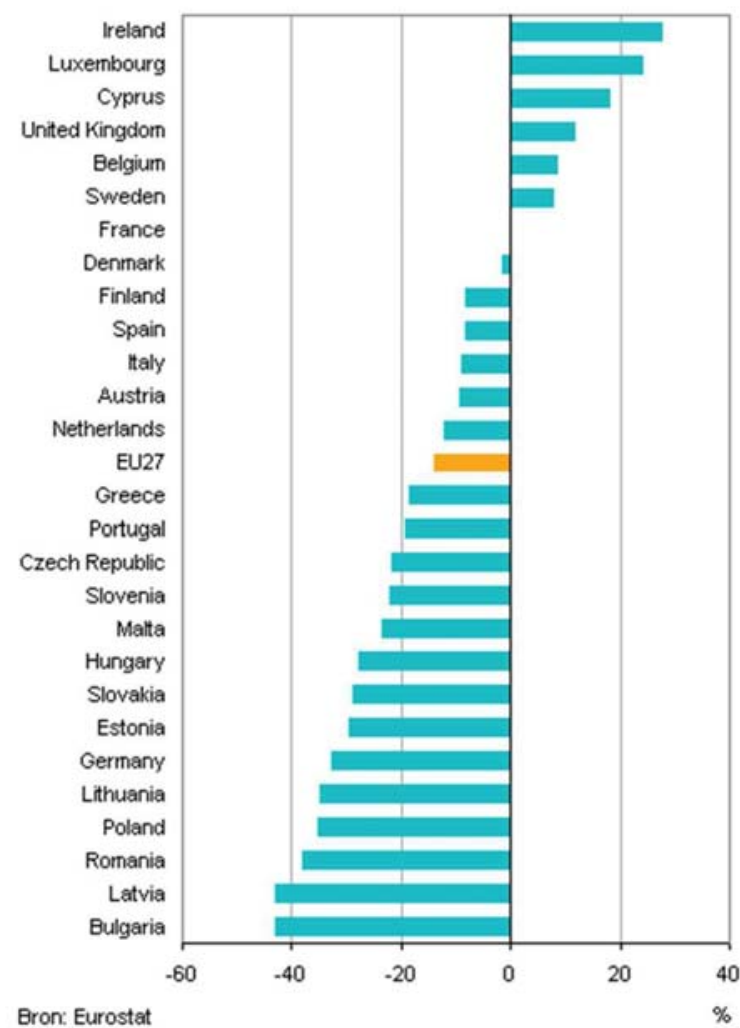

Figure 1: Development of labour force in EU countries, change from 2010 to 2060 (Statistic Netherlands 2012)

Nevertheless the health spending in Germany has been rising by an average of $2 \%$ over the years and exceeded the 300 billion mark for the first time in 2012 (Statistisches Bundesamt Pressequelle 2013). In total Germany has been spending $11.3 \%$ of its GDP on health insurance in 2011 which is less than the US spent but still more than most OECD countries did (OECD 2013). The most important reasons for the rising costs are the ageing population as well as the increasing demand for high quality medical care in the population (Porter, Guth 2012). The amount that the single worker will have to pay in the future might become prohibi- 
tive. We will explore various means by which the German system can improve its sustainability, leaving open the question how the problem of the demographical shift could be solved.

Before considering an idea of possible solutions, it is important to be aware of an adverse selection problem facing the German healthcare system. A critical difference between the SHI and PHI that you have to pay a contribution/premium for children and dependents in the PHI which is not the case in the SHI. On top, the contribution in the PHI is based on the health risk of the members. As a result, the members of the PHI are rather rich and healthy singles that do not incur a lot of health-related costs the so called "good risks", while the SHI has to deal with relatively more "bad risks" which reinforces the financial difficulties of the system. It is often seen as an injustice that the private insured do not participate in the social redistribution that the health care system as part of the German social safety network actually is aiming for. Additionally private insured people receive preferential treatment when they go to the doctor because the income that doctors are able to earn by having them as their patient is higher. This fact can have negative impacts on both of the different insurance groups - statutory insured might not receive enough treatment whereas private insured may receive too much of it (Greß, Rothgang 2010; Greß, Leiber, Manouguian 2009).

The government implemented a national health reform in the years 2007 and 2009 in order to prevent the SHI system from becoming unsustainable and increase the competition between SHI and PHI (Porter, Guth 2012). As a result the size of the contribution of the SHI is now determined by the government and no longer by the different sickness funds themselves. As a result they cannot compete with each other by setting low premiums or percentages of contribution anymore (Green, Irvine, Clarke, Bidgood 2013). Furthermore the Central Health Fund was established which collects all the premiums that the members of the different sickness funds and their employers pay. They then are redistributed to the separate funds based on different criteria like sex, age or morbidity rates of about 80 chronic and/or serious illnesses. If the money that the funds get is not enough to cover all the costs, their members to pay an additional contribution of any amount necessary (Green, Irvine, Clarke, Bidgood 2013). Another change within that reform was that now the suppliers of private health care have to accept all the applicants who did not have an insurance before but must be privately insured (such as freelancers) on a so-called "basis charge"(Barmer GEK). Furthermore switching from the SHI to the PHI is more difficult now then it was before the 2009 changes (Greß, Leiber, Manouguian 2009). The reforms led to an increase of the financial resources of the SHI sickness funds from 170 billion euros in 2009 to about 189 billion in 2012. Simultaneously the governments' tax spending to the funds of about 7 billion euros in 2009 doubled in the same period ("Gesetzliche Krankenversicherung - Kennzahlen und Faustformeln". Bundesministerium für Gesundheit, 2014). Although the sum of money available is now higher than before, the single worker and their employers are still carrying nearly the whole costs so that it is unlikely that the reforms lead to an improvement of their situation. 


\subsubsection{Policy Suggestions for the German Healthcare System}

A base for a solution which may relieve the single worker might be to start abolishing the private health insurance system (PHI) as it is facing serious financial problems, too, and integrate it into the system of statutory health insurance (SHI). Several ideas about this integration do already exist and one that is especially interesting is the so-called "Bürgerversicherung" which has been politically discussed for many years. The implementation of this system might take a long time but it aims for more social justice as it would no longer allow rich "good risk" people to insure themselves separately from the rest of the population. The problem of the adverse selection could be solved that way. The first step to restructure the system would be to no longer allow freelancers, public officials or people who exceed the necessary income limit for PHI to enter into it but to force them to enter into the SHI. As the abolishment of the PHI would make a lot of people lose their jobs it would be unavoidable to integrate the private sickness funds into the statutory system. The most significant change would be that the government would no longer allow them to set their contribution rates by measuring the risks of the new members so that all the premiums all over the county would be charged in the same way after some years: by looking at peoples' incomes and covering a certain percentage of it. Additionally it would be fair to also include other property such as rental, interest and investment income when setting premiums. This could be done by letting the Internal Revenue Service directly cover a certain percentage of the incomes and giving the money to the "Gesundheitsfond" where it then can be redistributed. Another aspect that the "Bügerversicherung" would change is that the income threshold would be set higher than its current income level such that prosperous people would be more burdened in order to increase the level of social justice within the health care system (Lauterbach 2004). There is also one thing that should be imported out of the PHI and integrated in the SHI system: everyone should be forced to build up reserves according to their possibilities that can be used for medical care in the old age. This could be organized by using one part of the percentages covered from employees to put it into huge bonds where the money could be collected. The ones who want to save more than the compulsory contribution would of course have the option to do that within the system. Another aspect that should be added to this idea is that people without children should have to build up higher reserves than people who do have children because the sustainability of the health care system depends on the existence of children in Germany who will be the future payers of the social safety network. It seems that it is not enough that families do not have to pay extra premiums for their dependents and children. The ones who do not have children threaten the existence of the whole health care system (and safety network) and therefore should be forced to carry more financial responsibility.

Based on a calculation of the year 2001, the contribution to the health care system in the "Bürgerversicherung" would only be at about $15 \%$ of the insured peoples' incomes in the year 2030. This would even be a lower contribution than it is now. The likely increasing prices based on technical progress as well as inflation 
and discounting have not been included in the calculation so that the percentage might be estimated a little higher based on todays' data (Lauterbach 2004). Still the number does show clearly that the "Bürgerversicherung" can be a future model for the health care system of the German society.

\subsection{The U.S. Healthcare System}

\subsubsection{Analysis of the U.S. Healthcare Sytem}

The U.S. Healthcare system is dominated primarily by the private sector. The U.S. does not provide universal healthcare service to the majority of its citizens. Instead, it is expected that employers sponsor healthcare for their employees. According to a 2003 statistic approximately $62 \%$ of non-elderly Americans have private insurance (Chua 2006). Despite this, the U.S. does have two government sponsored healthcare programs, Medicare and Medicaid, which are both part of the U.S. Department of Health and Human Services. Medicare is for senior citizens who are over the age of 65 . Americans over the age of 65 are virtually all insured by Medicare's federal government operated single payer system (Chua 2006). The other government program is Medicaid, which is designed to help impoverished or disabled Amercans. Unlike Medicare, Medicaid is operated by each state independently, but is partially financed by the federal government. The United States effectively has a mix of four different health-insurance programs, the single payer system (Medicare, where all payments go through the government and paid for with payroll taxes), the privatized version of the Bismarck model (where employees pay into an insurance plan with their companies), the Beveridge system (Medicaid, where government's collect taxes and redistributes a percentage to health insurance) and the out of pocket system (where citizens with no insurance pay cash for service). Having a mix of four different systems makes the American system more unique compared to most other countries and creates different sets of issues than EU nations would face.

While the U.S. has shown an overall average increase in life expectancy over the last decade, it still lags significantly behind most other developed nations in life expectancy and health related issues. Most OECD countries' life expectancies have also been improving at a faster rate than the U.S. (JAMA 2013). The OECD average life expectancy is 80 years while in America it is 78 years (OECD 2014). Despite average U.S. life expectancy increasing, there has been a decrease in life expectancy in many communities and population groups across the U.S. These decreases have been attributed to problems relating to inadequate access to health care. One reason for lack of access to health care is due to affordability. Millions of Americans are denied healthcare solely because they cannot afford it (out-ofpocket model) and as of 2012 over 16\% of Americans were left uninsured (CDC 
2, 2014). If underinsured Americans are included the number rises even further to $34 \%$ (Nunley 2014). These citizens cannot afford health services despite the fact that the U.S. spends about $17 \%$ of its GDP on healthcare (OECD average is $9.3 \%$ ), but the U.S. healthcare system only helps a small percentage of the population with almost double the expenditure (OECD 2014). Also, the U.S. spends the most per-capita on healthcare in the world, but still the population's health is equal or lesser-than other OECD countries who spend substantially less on healthcare (Diggs 2012).

Part of the reason for low healthcare outcomes in the U.S. is that there is institutional discrimination that is tolerated within the American healthcare system (Diggs 2012). Some examples of this institutional discrimination may involve race or certain socio-economic classes (or a combination of both). For instance, African-Americans and Hispanic populations compared to white populations statistically have the lowest access to healthcare and therefore the lowest health outcomes as compared to white populations (Diggs 2012). Socio-economic factors are also another major contributor to discrimination seen in the healthcare system. This is because if a person is poor they may not have access to insurance nor the means to pay for health care. Also, people living in certain impoverished regions may also have access problems to adequate healthcare, in that they may have difficulty finding adequate healthcare facilities in their area, especially in inter-city or rural areas (Diggs 2012).

\subsubsection{Policy Suggestions for the U.S. Healthcare System}

If the U.S. expects to increase life-expectancy and overall health and wellness for all sectors of the population, it needs to change its policies and laws to reflect that healthcare is a right, not a privilege. This is because healthcare is something that all humans require. If the U.S. does change to this policy (or have a culture shift in this direction) it will enable all Americans access to healthcare and thus reduce healthcare disparity. Furthermore, the U.S. needs to work to reduce health care costs for all Americans and increase healthcare coverage. The U.S. has attempted to solve policy issues related to efficiency, adequate care and healthcare accessibility recently with the Patient Protection and Affordable Care Act. Despite these new policies, the government still has not gone far enough to address the needs of society and still not everyone will receive coverage (JAMA 2013).

The Patient Protection and Affordable Care Act was designed to expand medical coverage to cover the majority of Americans. The Affordable Care Act also made it legal to penalize citizens who have not signed up for health insurance effectively making health insurance mandatory. One of the ways it was to achieve this goal was the expansion of Medicaid (KY Cabinet 2014). Under the Affordable Care Act, Medicaid expansion was expanded to cover up to $138 \%$ of the federal poverty level. Despite this expansion, not all states are required to expand Medicaid due to a Supreme Court Ruling eliminating the possibility of penalizing states for not expanding coverage. After the March 2014 deadline for signing up 
for insurance under the Affordable Care Act (to avoid penalization), a McKinsey study noted that over $74 \%$ of the sign-ups were from people who had pre-existing insurance (Forbes 2014). A Gallup survey also stated that after the 2014 sign-up ended, the uninsured rates in the U.S. dropped to $13.4 \%$ and that many of the newly insured citizens were from minority populations such as Hispanic or Black. Gallup also found that the highest rates of newly insured citizens occurred in states that expanded Medicaid (Gallup 2014). However, not enough data has been collected to take into account the number of underinsured citizens, as many of the new insurance sign-ups may only include life-threatening coverage. Another issue with the Affordable Care Act is that the expanded service mostly helps lowerincome citizens due to only a partial expansion of Medicaid, but does not do much to provide full health insurance coverage to middle class Americans, as their only option is private insurance usually from their place of work.

As the Gallup data above shows, the states that had the highest increase of newly insured citizens were in states that increased Medicaid. This data shows that the best way to improve the Affordable Health Care Act would be to expand Medicaid (or add another public option) for everyone. This would decrease the uninsured and underinsured rates.

\subsection{The Italian Healthcare System}

The following paragraph will give an overview of the history of the Italian Health System and development nowadays to analyze its strengths and weaknesses. Policy recommendations will be given under the consideration of national entities. All policy recommendations below aim into the direction of supporting a greater equality in Italy in accordance with European Union values and strategies.

\subsubsection{Analysis of the Italian Healthcare System}

The Italian National Health System was established as recently as 1978. The system was originally set up as a three-tiered system divided between the central government, regions, and then finally local health authorities (Aziende Sanitarie Locali). The central government was in charge of setting price ceilings and redistributing national health care funds to regions based on need and poverty levels (G. Francea, et al, 2005). In reality, however, these funds were distributed disproportionately and based on political preferences at the local level. This control on the local level caused problems because national funding ceilings were regularly exceeded by the local authorities budget problems (G. Francea et al., 2005). 


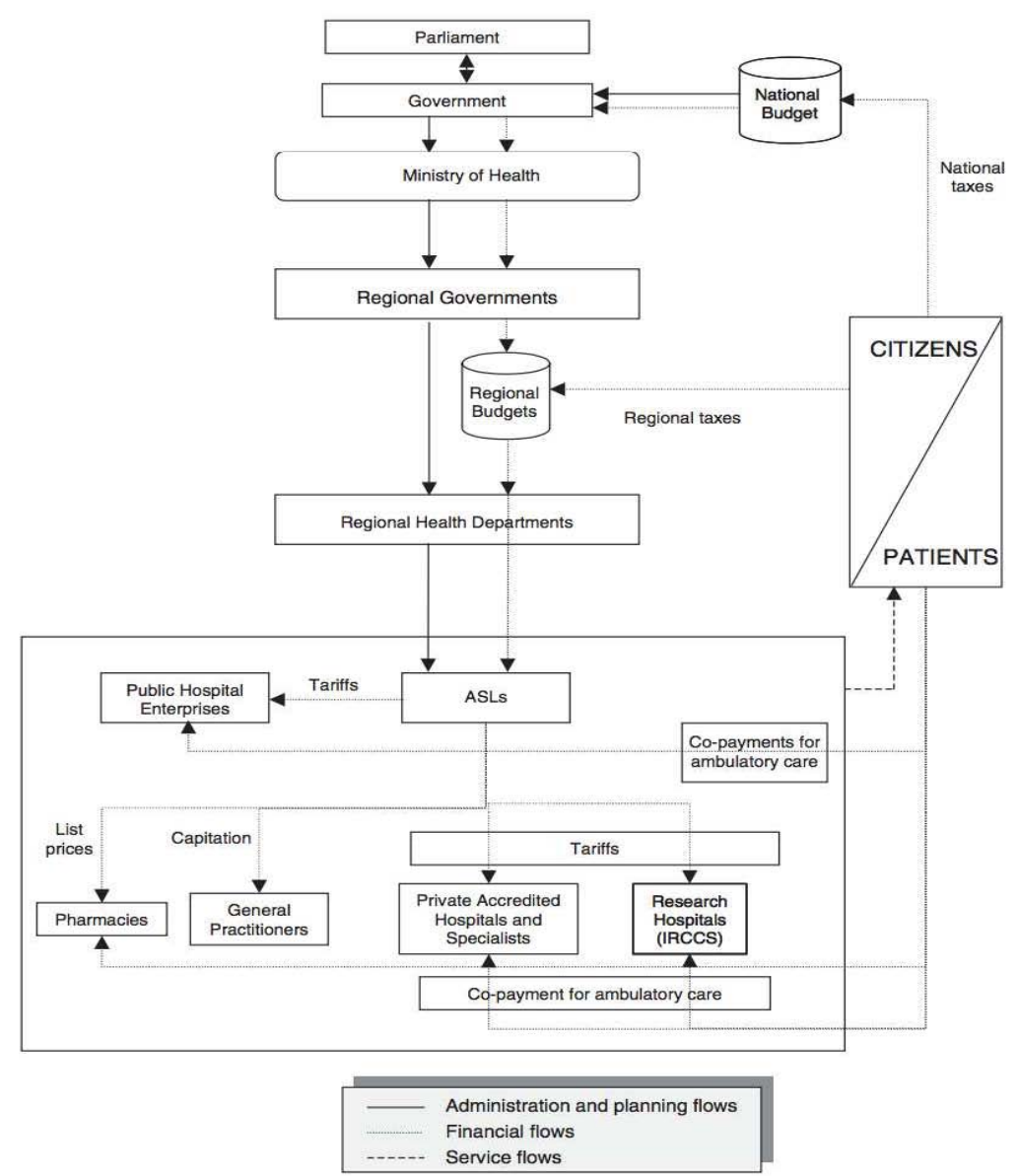

Chart 1. The Italian National Health Service (2002)

1 Source: G. Francea et al., 2005

In 1992, the central government decentralized healthcare financing and gave away more authority of the health system to the regional governments. The motivation behind this measure was that shifting responsibility to the local level would create more efficiency in the system, as the regions could better accommodate their own healthcare priorities, as compared to the central government. Furthermore, the policy makers hoped local financing would help fix issues of misspending or overspending of national health funds. The development was a central government that sill plays a roll but only as a provider of general guidelines.

Currently, the 20 regions in Italy are able to decide how much they want to spend on health care, resulting in a wide variation of healthcare models. Some re- 
gions of Italy, such as Lombardy have embraced a privatization or "marketization" of the healthcare system, while others have embraced a cooperative approach (L. Frisina Doetter, et al, 2011). This second approach involves private and public healthcare working together or complimenting each other rather than direct competition.

\subsubsection{Policy Recommendations for the Italian Healthcare System}

An unintended consequence of the regionalization of the healthcare system was that the abuse of power by politicians started becoming more prevalent. Some regions spend up to $70 \%$ of their budget on health care so such that healthcare has become a political tool (European Commission and the Economic Policy Committee (AWG), 2010). The biggest issue since the inception of the healthcare system until now has been curbing healthcare spending. Because healthcare costs are so high in many areas, taxes have also gone up. This has created economic distortion in the system, as black markets and bartering have become a way to avoid high taxes (David Maris, 2012). Italy's biggest healthcare issue has been to curb this spending, especially in regards to the terms of the EU's Maastricht criteria. Those are the criteria, which EU member states have to fulfill to enter the third stage of the Economic and Monetary Union (EMU) in order to adopt the Euro as their currency. (Economic and Financial Affairs, 2014)

The caretaking of the elderly by the families is one of the role model aspects in the Italian health care system. The responsibility for taking care of the elderly lies solely with their families, as little is provided by the government in terms of elderly care. When elderly family members are sick in southern countries like Italy most of the time the family takes care of them at home instead of in retirement homes or hospitals. This works well for Italy but it couldn't be easily transferred to every country because of different familial structures. In northern countries it is not as common as in Italy that three generations live in one house or close to each other anymore. Young people often move out in order to study or to work (Alessandra Rusconi, 2006). A possibility to mirror this on other countries would be through a national substitution policy in monetary form. Families of the northern countries would receive money from a newly installed national fund in case they take care of the elderly people. The southern European countries could use similar measures to increase the level of family responsibilities.

Another major issue with the system is the great economic inequality between the south and the north (Table 1) which led to large migrations of people (in 2001 it was 860.000 which is an increase of $7.5 \%$ from 1997) moving from regions like Sicily and the region of Campania to northern regions' of Emilia-Romagna and the region of Lombardy (Alessandra Rusconi, 2006). This has put more stress on northern regions healthcare systems. 
A midterm solution could be transferring healthcare administration to national control again to prevent the great inequalities. The European Union member states policies are moving into the direction of national controlled policies. Many nationalistic movements were founded in the last years, which want to diminish the influence of the European Union on national policymatters (Andrew Rettman, 2014). Through health care insurance bills the Italian government could establish a superregional healthcare system again with a consistent health care level that is equal for all 20 regions in Italy. Furthermore this could diminish another problem that comes with the regional division of the health care system, the influence of local politicians and the abuse of regional funds. National funds would be an optimal solution in order to establish a greater balance between North Italy and South Italy. In the long-term a coherent EU health care policy, which will be discussed below, would be a solution of interest but this solution would be hard to apply given the current political climate.

Table 1. Selected indicators of interregional variation -2002 (or nearest year)

\begin{tabular}{|c|c|c|c|c|c|c|c|c|}
\hline & \multirow[b]{2}{*}{ Italy } & \multicolumn{2}{|c|}{ Northern } & \multicolumn{2}{|c|}{ Central } & \multicolumn{2}{|c|}{ Southern } & \multirow[b]{2}{*}{$\mathrm{CV}(\%)$} \\
\hline & & $\operatorname{Max}$ & Min & $\operatorname{Max}$ & Min & $\operatorname{Max}$ & Min & \\
\hline Population $(\times 1000)$ & 57321 & 9109 & 121 & 5146 & 834 & 5725 & 321 & 81.2 \\
\hline$\%$ elderly population ( $>65$ years) & 18.6 & 25.4 & 15.8 & 22.6 & 17.7 & 21.4 & 14.2 & 14.8 \\
\hline GDP $(€ 000)$ per capita $^{\mathrm{a}}$ & 20.1 & 26.8 & 21.7 & 22.3 & 19.5 & 17.1 & 12.4 & 25.2 \\
\hline \multicolumn{9}{|l|}{ Life expectancy at birth } \\
\hline Male & 76.8 & 77.2 & 76.5 & 78.1 & 76.6 & 77.8 & 75.4 & 0.8 \\
\hline Female & 82.9 & 83.6 & 82.7 & 84.0 & 82.4 & 83.9 & 81.2 & 1.0 \\
\hline Infant mortality $(\%)^{\mathrm{a}}$ & 4.5 & 4.6 & 2.4 & 4.7 & 3.1 & 6.2 & 4.0 & 27.3 \\
\hline Perinatal mortality $(\%)^{a}$ & 5.7 & 6.4 & 3.5 & 5.7 & 4.1 & 7.4 & 3.2 & 24.1 \\
\hline Hospital beds (\%o inhabitants) ${ }^{b}$ & 5.0 & 6.0 & 4.3 & 5.9 & 4.4 & 5.0 & 3.8 & 11.5 \\
\hline Private hospital beds $(\%)^{\mathrm{b}}$ & 13.8 & 21.7 & 0.0 & 30.8 & 7.0 & 34.2 & 2.3 & 70.5 \\
\hline Private hospital admissions (\%) & 13.7 & 19.3 & 0.0 & 15.9 & 5.5 & 24.7 & 1.9 & 61.1 \\
\hline Public health-care expenditure per capita $(€ 000)^{\mathrm{b}}$ & 1.4 & 1.9 & 1.4 & 1.5 & 1.4 & 1.4 & 1.2 & 11.1 \\
\hline Prevention $(\%)$ & 4.3 & 6.0 & 2.8 & 5.1 & 3.0 & 6.5 & 3.3 & 25.5 \\
\hline Hospital (\%) & 48.1 & 53.8 & 43.8 & 50.1 & 44.4 & 50.5 & 47.0 & 5.6 \\
\hline Drugs $(\%)^{\mathrm{c}}$ & 15.1 & 17.3 & 10.0 & 17.2 & 14.8 & 19.1 & 15.5 & 14.9 \\
\hline Community services (\%) & 32.5 & 38.0 & 29.1 & 36.1 & 29.7 & 32.6 & 27.9 & 6.7 \\
\hline
\end{tabular}

Sources: [4,7-9]. Northern regions: Val d'Aosta, Piemonte, Lombardia, Veneto, Friuli-Venezia-Giulia, Trentino Alto-Adige, Liguria, Emilia-Romagna. Central regions: Toscana, Lazio, Umbria, Marche. Southern regions: Campania, Molise, Abruzzo, Puglia, Basilicata, Calabria, Sicilia, Sardegna. CV: Coefficient of variation.

2000.

b 2001 .

${ }^{\mathrm{c}}$ Distributed via retail pharmacies only.

The current focus for EU action in health policy is defined in Article 168 of the Treaty on the Functioning of the European Union. The concept is that human health is valuable and accounted for in the development of all EU policies and activities. "EU action to encourage cooperation between Member States shall in particular concern the improvement of their health services in cross-border areas" (Article 168 of the Treaty on the Functioning of the European Union). Article 168 
also states that the European Union should acknowledge the freedom of individual member states to define their own health policies and organize and deliver their health services and medical care, including any resources assigned to them.

The European Union's task is to complement the policies of the EU members on issues where coordination, cooperation and exchange of information are needed. It also uses legislative powers to control certain areas.

In 2007 the European Union created policy to standardize health standards, which is based on four key points. First, shared health values must be defined across all nations, secondly health must be seen as the most important right, thirdly considerations about health must be included in all policies and lastly EU healthcare policies supersede national policies on all issues affecting global health.

Thus three key objectives were identified; provide good health in an aging Europe, health threat protection like in the case of an epidemic and the support of innovative health systems and technologies. These three principles can be transferred to the Italian system.

These objectives complete the aims of the Europe 2020 strategy, which can be a valuable orientation for the Italian government for smart and sustainable growth. Focused investments in healthcare, productivity and innovation, building new abilities, are measures to help to reduce inequalities and create more sustainable health systems. In February 2013, the European Commission passed a bill called 'Social investments for growth and cohesion'. One aspect of this package focuses on investments in health. The conclusion is that health is a value in itself, and also a key to economic prosperity. Sustainable health systems are a key focus, investing in people's health as human capital, and investing in reducing inequalities in health can contribute to economic growth. The European Union will support reforms through its funding instruments, i.e. 'Structural Funds and health program'.

These funding instruments can be used to assist the Italian structural changes back into a governmental controlled healthcare system. Furthermore the aimed health care reforms will be nationally supported to strengthen the positive aspects like the caretaking of the elderly in Italy.

\subsection{Comparison of the German, U.S. and Italian Healthcare Systems}

The three health care systems are based upon different models of health care systems. Italy is using a form of the Beveridge Model as their health care is funded through taxes and the regional governments decide how the money will be used. As explained earlier the main problem of the Italian system results exactly from the power that politicians have concerning the financing of health care and therefore tend to spend too much money on it. For that reason, it might be necessary to implement some aspects of the Bismarck Model in the Italian health care system as it does not give all the power to the government but just is controlled by it. 
Therefore Italy can use the German statutory system as a role model. The reason for that is, that the Bismarck Model works very well in Germany concerning the distribution of health care and the universality of the system as the providers of insurance are private and the government is only regulating them. The redistribution from rich to poor and from healthy to sick might also be a way to improve the differences between the Italian regions and their financial resources which might make the system more just. Germany can also be a role model for the US in some points as their health care system is strongly influenced by politicians as well because they are trying to implement reforms to improve health care in the US. For that reason the American health care system consist of four different health care models and still does not provide universal health care for everyone. It might have to choose one model and then start to establish it for every part of the society. Therefore the US could also use the German system as a role model for their system and adopt some of the aspects to make their system more homogeneous. The Bismarck model might work better than the Beveridge Model because most of the insurance providers and hospitals in the US are already private and it would be too much of a financial effort for the state to nationalize them.

\section{Effects of Globalization on Health}

The health sector with a spending of 3.2 trillion dollars in the year 2003, which was about 10 per cent of the global GDP, is one of the worlds' hugest industrial sectors (Lister 2008). Globalization had an important influence on the development of the worlds' health sector and also on reforms that have been implemented in different countries concerning their health systems. Most of the reforms, which were mainly implemented in middle or low income countries, aim for supporting the extension of the private health sector and its importance and influence on the provision of health care because they are strongly influenced by global organizations such as the IMF or the World Bank (Lister 2008). All in all, globalization brings along a number of advantages but also supports the expansion of disadvantages as will be explained in this text.

On the one hand the great importance of the health sector makes it nearly impossible for politicians to ignore the topic or to reduce financial resources in this sector as the political debate is also driven forward by NGOs, health workers trade unions and other organizations that deal with the health topic. This can be an advantage because most of these organizations promote health care as a public service and want it to improve (Lister 2008). Another advantage of globalization might be that trough the rising spending on health the medical knowledge in the world is also rising. As a result, the ability to heal more illnesses and the awareness of the development of new drugs and treatments is recognized all over the wqorld. This awareness leads to an increase of the pressure to offer this methods (Lister 2008). 
On the other hand it is also this huge influence of the health sector that brings along a number of disadvantages. Some of the reforms (that these low and middle income) governments made led to the image of health care as an "economic transaction" rather than a "public good" which made the increasing privatization of the health care sector even easier. Most of those private providers do preferentially treat the wealthier part of the population which on top has a lower health risk. The public providers of health care suffer from that, as they as a result need to deal with all the poorer and sicker individuals. The reforms obviously are not driven by the necessity or demand for private services but by political pressure that comes from influential global institutions (Lister 2008).

Another aspect of globalization is a great external and internal movement of health workers "brain drain". The external movement is an emigration of health workers from poor (usually southern) countries, for example India, South Africa or the Philippines, to rich (mainly northern) countries like the US, the Middle East, the UK or Australia. These movements have disastrous consequences for the poor countries where these qualified workers would be needed very urgently to provide medical services for the population. The internal brain drain is the movement of health workers from the public into the private health sector - and with it the movement from rural regions into cities where the private services are mostly provided. This effect even enlarges the problems for the poor population to get access to medical care as they on the one hand cannot afford it and on the other often do live in these rural areas. The motive for the health workers to either emigrate or work in the public sector is clearly the higher wages they get from it and it is their strategy to survive (Medico International 2004).

Another factor that increases the lack of health workers who provide health care for the poor is the medical tourism which became very famous in some countries like Thailand or Bangladesh. This medical tourism is often offered by huge hospitals in cooperation with Joint Ventures and of course they are private providers who offer a lot of employment with higher wages than public hospitals could. For rich countries where the tourists usually come from this development is positive because even complicated treatments are far cheaper than in thehome countries (Medico International 2004).

All in all it is clear, that poor countries are rather the losers of the globalization of health care whereas especially the private health providers of the western health industry profit from the exchange of medical services.

\section{European Union Health Care plans and future policies}

This section gives an overview over the historical and current policies implemented by the European Union member states. These policies are used as a foundation for future policy recommendations. Thus the European Union is already moving towards a united policy concerning health cards that work in all of the EU, this can be seen as a first step forwards to coherent EU health care policies. All the policies 
mentioned in the sections below move into the direction of an international healthcare system, from which all the European Union citizens would benefit. Overview of EU Healthcare Policies

\subsection{Historical and current overview of EU healthcare policies}

This paragraph, which is the rational for our policy recommendation, explains that the EU is slowly moving towards a continental social system and healthcare has been part of this change. Below are all the steps from 2003 that the EU has been taking towards a single social healthcare network.

On 13 December 2007 the heads of state and government of the 27 EU Member States signed the Lisbon Treaty called, Treaty on the Functioning of the European Union (TFEU). It is intended to reform the functioning of the European Union following the two waves of enlargement, which have taken place since 2004 and which have increased the number of EU Member States from 15 to 27. The article 168 belongs to Title XIV Public Health and states:

"A high level of human health protection shall be insured in the definition and implementation of all Union policies and activities. Union action, which shall complement national policies, shall be directed towards improving public health (...), A high level of human health protection shall be ensured in the definition and implementation of all Union policies and activities. Union action, which shall complement national policies, shall be directed towards improving public health" (European Union, 2003 -2014)

The European health policies went through three steps in their development: Public Health Programme (PHP), Second Programme of Community Action in the Field of Health, Third Health Programme. The Public Health Programme 20032008 ran from 1 January 2003 to 31 December 2007. The program aimed to protect and improve EU members' health care systems. It promoted work in the following three main areas: health information, rapid reaction to health threats and health promotion through addressing health determinants (European Union, 2003 2014). The Second Programme of Community Action in the Field of Health 20082013 came into force on 1 January 2008. It is intended to complement, support and add value to the policies of the Member States and to contribute to increased solidarity and prosperity in the European Union by protecting and promoting human health and safety and by improving public health (European Union, 2003 2014). The Third Health Programme is the main instrument the European Commission uses to implement the EU Health Strategy stated in article 168 of TFEU. It runs from 2014 until 2020 and the main scopes are to promote health, protect Union citizens from serious cross-border health threats, encourage innovation, efficiency and sustainability in health systems and facilitate access to better and safer healthcare for Union citizens. This programme emphasizes the Europe 2020 strategy for intelligent, sustainable and inclusive growth stated in the European Health Strategy 'Together for Health'. One of the main concerns is the protection 
of citizens from serious cross-border health threats in order to improve the cooperation with neighboring countries. The program is open to the participation of potential candidates benefiting from a pre-accession strategy, in accordance with the general principles and general terms and conditions for their participation in Union programs established in the respective Framework Agreements, Association Council Decisions or similar Agreements; EFTA/EEA countries in accordance with the conditions established in the EEA Agreement; neighboring countries and the countries to which the European Neighborhood Policy (ENP) applies in accordance with the conditions laid down by a relevant bilateral or multilateral agreement; other countries in accordance with the conditions laid down by a relevant bilateral or multilateral agreement (European Union, 2003 -2014). The implementation is based on annual work plans, which set out priority areas and the criteria for funding actions under the Programme (European Union, 2003 - 2014). Moreover, it considers the following steps: monitoring the implementation of the actions, reporting to the Programme committee, evaluating the impacts at mid term by the end of June 2017 and ex-post long term impact, making the results publicly available and widely disseminated (European Union, 2003 - 2014)

The aims of the European Union emphasize the role of a highly developed health system in promoting productivity at work, economic competitiveness and higher living quality.

The fields of interest are investing in sustainable health systems, in people's health as human capital, in reducing health inequalities. Increasing the financial effectiveness through reforms and investments is crucial. Investing in health care specifically in precaution medicine can lead to a more effective spending without increasing the input financing. Thus generally the effects on health care can be expected to be of greater influence. It may take different approaches, such as change in the structure of health care departments to improve efficiency while improving the benefits for the society, investment in healthcare staff, training or equipment and initiatives to promote good health and prevent diseases.

The avoidable morbidity and mortality resulting of health inequalities represent a loss of human capital that must be diminished. General availability of healthcare services, increased cooperation between social and healthcare services and new health policies in order to prevent avoidable diseases can result in an important contribution to economic productivity and social comprehension.

Policies could foster cost-effective innovation to generate increased health outcomes. In the long-term view these measures should avoid increasing disease and financial burdens. Financially reasonable systems and structural changes of health systems need to support public policy aims guaranteeing an overall improvement of the healthcare system. As a part of the reforms within the context of Europe 2020 this should be accomplished. As you can see, European Union is continuously trying to improve the cohesion of the international healthcare system. 


\subsection{Policy suggestions for future EU Healthcare Policies}

Due to the EUs policy towards a more coherent and unified healthcare system it is important for policy makers to start looking at long-term EU policy goals in regarding healthcare. This is because the advantages of more coherent European policies can already be seen resulting in benefits for the citizens. Policy recommendations go into the direction of extending these efforts.

The European Union could establish a minimum health care system in their member states. Through a stakeholder analyses the European Union could acknowledge winners and losers. Winners would be regions with a lower developed health care system, which would profit in terms of structural changes. Looser might be regions that already have a highly developed health care system and profit from health care tourism. In an optimal case there would be no losers. Minimum requirements for health care would not threaten regions with a better developed health care system. Those regions still keep their advantage of a good health system thus they generate health care tourism. Another policy recommendation would be a "Luxury tax" on additional health insurance; if citizens want to have insurance above the basic level they are usually wealthier. Thus an additional 10\% tax could be established on this insurance to help financing the people that are not able to pay their insurance by themselves. "Since 1998, member states have no longer been permitted to discriminate against citizens of other member states when disbursing social benefits," says 
Kingreen (Spiegel, 2014). This law can be used as a legal foundation for supranational European Union policies in the field of health care.

Furthermore integration efforts need to consider health care as well to insure equal treatment for all the citizens.

First steps into the direction are already made through health care cards of the European Union, which already include the European symbols on it and work in all of Europe. There is no the need for additional travelling insurance in the boundaries of the EU; though the services provided by the Insurance programs are still varying significantly in each country or region.

Another policy could be the establishment of a EU subsidy fund for the caretaking of the elderly at their families' homes instead inside of retirement homes or hospitals. The Italian system could be seen as a role model in this field. Family boundaries are stronger, so for most of the people in Italy it is self-evident. Implementation in the Northern EU countries through subsidy would be an admirable goal (Nesti, G, et al, 2003).

In the long-term the USA-EU trading Zone could be extended in to other policy fields, such as health insurance. The usage of the best practice method would be an optimal solution in order to find out about the advantages and disadvantages of each system.

\section{U.S. and European Global Healthcare Policy Suggestions}

As the above section mentions, the EU is already moving towards an "international healthcare zone", where EU citizens can ac- 
quire access to healthcare in other EU states if they have an EU health insurance card (EU 2014). The benefits of the EU health insurance card is that if people from one EU state visit another and need sudden medical care, they will be able to receive it at reduced or minimum cost (similar to the cost of a citizen of the host country). Other benefits are that it helps reduce barriers between countries, and creates more efficiency in the healthcare system if multiple countries healthcare systems cooperate and coordinate with each other especially in a time of increased globalization and increased necessity for traveling. A policy recommendation would be to expand the EU Health Insurance Card to North America as well to create a single health zone, where all member states can have access to similar benefits.

The rationale for the expansion of the EU Health Insurance Card lies in the foundation of the Trans-Atlantic Trade and Investment Partnership (TTIP). The foundation of TTIP is to create a single market between the United States and the EU, where goods on both sides of the Atlantic can be traded freely (Europa 2014). The current issue is that both the EU and the U.S. have their own separate regulations and standards on safety, health, regulation etc. which creates compliance problems for companies wanting to sell in both markets. TTIP is working to fix this problem by possibly creating a common set of standards for health and safety for both markets. In addition to reducing costs, TTIP will create further benefits. One of these benefits is that both EU and American policy-makers and regulators will have to work closer 
together and are thus able to exchange and learn from ideas on both sides of the Atlantic (TTIP PDF 2013). Also, if common standards are achieved, these are more likely to become international standards which will could result in an increase of standards globally.

If TTIP does get enacted by The EU and the US it would create a solid framework for expansion of a single healthcare zone. TTIP could even be expanded to include healthcare in future talks. As stated above, collaboration on other safety and health standards would increase efficiency in the economic system, create an exchange of policy ideas, and could set international standards. The same logic could be said for a similar dialogue on allowing for an international healthcare zone. This is because, to allow such a zone, a core of common standards for healthcare would have to be met, which would create discussion and policy adjustments that could make healthcare in both zones more effective and efficient.

Furthermore, according to the U.S. Office of Travel and Trade approximately over 11.2 Americans traveled to Europe in 2012, while approximately 12.4 million Europeans traveled to the U.S. (ITA 2014). That is approximately 24 million people who would benefit from an international health zone policy. If the policy is further expanded to all of North America, including Canada and Mexico, the number of beneficiaries would increase even more. The one issue that may be a stumbling block to implement this policy would be the U.S.'s lack of universal government backed healthcare, like in Europe. This problem could 
potentially be remedied by making a provision that visitors who are in the U.S. and have a "North Atlantic" Health Insurance Card could have access to an expanded Medicaid service (either at a full discount rate like American citizens, or a slightly more expensive, but still subsidized rate).

\section{Conclusion}

After having analyzed the American, Italian and German healthcare systems it is pretty clear that all of the three models do have some advantages and some serious problems they have to deal with. The US provides medical services of high quality to some parts of the society but it needs to work on establishing a health system which is more universal and accessible to everyone. In Italy the idea of letting regional governments decide about the amount of health care needed can be a good idea but it needs to be reorganized so that politicians cannot abuse the system for their own aims. In Germany the system includes a redistribution that allows poor people to receive the same services like the richer part of the population but the system is threatened by a demographical shift. In the end there is not a "perfect" health care system that may work in every part of the world as every country has its own priorities that are accepted in the society. Still the situation could be improved if the EU and the US would work together on a standardized health zone as healthcare in general is becoming a more and more globalized topic. Furthermore some of the national problems that Italy, the US and Germany have to deal with could be 
solved with these points. Healthcare definitely must be treated as a public right that everyone should have access to which also includes medical treatment that is affordable for everyone including minorities. 
Works sited: 
Alesina, Alberto et al. "Why Doesn't the U.S. have a European

Healthcare System." National Bureau of Economic Re-

search.Cambridge.2011 Oct. <

http://www.nber.org/papers/w8524>

„Beitragssatz und Zusatzbeiträge der gesetzlichen Krankenversicherung", Bundesministerium für Gesundheit, 26 March 2014. Web. 15 May 2014.

http://www.bundesgesundheitsministerium.de/krankenversicheru $\mathrm{ng} /$ beitragssatz.html

„Bismarcks Sozialgesetzgebung (1881 - 1889).“ In die Zukunft gedacht. Bilder und Dokumente zur deutschen Sozialgeschichte. Bundesministerium für Arbeit und Soziales, Web. 20 May 2014 https://www.in-die-zukunftgedacht.de/de/page/68/epoche/129/epochen.html

Burkhardt, Wolfram. „Einer für alle, alle für einen - Das Solidarprinzip in der gesetzlichen Krankenversicherung", Bundeszentrale für politische Bildung, 16 December 2013. Web. 15 May 2014. http://www.bpb.de/politik/innenpolitik/gesundheitspolitik/72358/soli darprinzip

CDC. "Health Expenditures."Center for Disease

Control.last accessed May 27, 2014.http://www.cdc.gov/nchs/fastats/hexpense.h tm

CDC 2. "Health Insurance Coverage."Center for Disease Control.last accessed May 27, 2014.http://www.cdc.gov/nchs/fastats/hinsure.htm Chua, Kao-Ping. "Overview of the U.S. Healthcare System."American Medical Student Association.2006 10 Feb.<http://www.amsa.org>.

“Deutschland - ein Verlierer beim aktuellen Ranking der europäi- 
schen Gesundheitssysteme." Health Consumer Powerhouse, 15 May 2012. Web. 14 May 2014

Diggs, Schnequa. "Health Disparities and Healthcare Financing."Journal of Health Care Finance.2012; 38(4) pp.76-90.

Economic and Financial Affairs, 2014 http://ec.europa.eu/economy_finance/euro/adoption/wh o_can_join/index_en.htm

European Commision. "European Health Insurance Card."European Commission.last accessed May 27, 2014.<http://ec.europa.eu/social/main.jsp?catld=559>. Spiegel Staff. "Welfare for Immigrants:EU Wants Fortress Germany to Open Up."Spiegel Online.last accessed May $27^{\text {th }}$, 2014.<http://www.spiegel.de/international/germany/brusselsmayforce-germany-to-loosen-access-to-social-benefits-a-943224.html>. 
European Commission 2. "Transatlantic Trade and Investment Partnership; The Regulatory Part."European Commission. September 2013.

$<$ http://trade.ec.europa.eu/doclib/docs/2013/july/tradoc_15160 5.pdf>

European Commission 3. "What is the Transatlantic Trade and Investment Partnernship?"European Commission.last accessed May $27^{\text {th }}, 2014 .<$ http://ec.europa.eu/trade/policy/infocus/ttip/about-ttip/>.

European Commission and the Economic Policy Committee (AWG), Joint Report on Health Systems, 2010 http://ec.europa.eu/economy_finance/publications/occasional_paper /2010/pdf/ocp74_en.pdf David Maris, 2012, http://www.forbes.com/sites/davidmaris/2012/11/07/us-healthcarewelcome-to-italy/, 05/23/14

European Union 1, 2003 -2014, http://eurlex.europa.eu/JOHtml.do?uri=OJ:C:2008:115:SOM:EN:HT $\mathrm{ML}, 05 / 25 / 14$

European Union 2, $2003-2014$ http://ec.europa.eu/health/programme/docs/factsheet_healthprogr amme2014_2020_en.pdf

European Union 3, $2003-2014$ http://ec.europa.eu/health/programme/policy/ 2003-2008/index_en.htm European Union 4, $2003-2014$, http://ec.europa.eu/health/programme/policy/2008-

2013/index_en.htm

European Union 5, 2003 -2014, http://ec.europa.eu/health/programme/docs/ev _20141104_co01_en.pdf 
European Union 6, 2003 -2014, http://ec.europa.eu/health/program me/policy/index_en.htm

European Union 7, 2003 -2014, http://ec.europa.eu/health/programme/docs/factsheet_healthprogr amme2014_2020_en.pdf

European Union 8, 2003 -2014,

http://ec.europa.eu/health/programme/key_d ocuments/index_en.htm

European Union 9, 2003 -2014, http://ec.europa.eu/health/program me/policy/index_en.htm

European Union 10, 2003 -2014, http://www.epha. org/spip.php?arti cle2434 
Frisina Doetter, Lorraine, et al, The Changing Role of the State in the Italian Healthcare System, 2011,

http://onlinelibrary.wiley.com/store/10.1111/j.1467-

9515.2011.00786.x/asset/j.1467-

9515.2011.00786.x.pdf? $v=1 \& \mathrm{t}=\mathrm{h} v \operatorname{tajaco} \& \mathrm{~s}=50 \mathrm{db} 836 \mathrm{f} 2 \mathrm{c} 7669041 \mathrm{fd} 3 \mathrm{e}$

03c5f4070adf1b0d7c0, 05/16/2014

van der Gaag, Nicole. "The potential labour force of the European Union: from growth to decrease." Statistics Netherlands., 04 October

2012. Web. 15 May 2014 http://www.cbs.nl/en-

$\mathrm{GB} / \mathrm{menu} /$ themas/arbeid-sociale-

zekerheid/publicaties/artikelen/archief/2012/2012bevolkingstrends-

beroepsbevolking-eu-art.htm

"Gesetzliche Krankenversicherung - Kennzahlen und Faustformeln."

Bundesministerium für Gesundheit, 2014. Web. 16 May 2014

http://www.bmg.bund.de/fileadmin/dateien/Downloads/Statistiken/

GKV/Kennzahlen_Daten/K F2014Bund_Januar_2014.pdf

"Gesundheit in Zeiten der Globalisierung." Medico International, Umwelt-Medizin-Gesellschaft, UMG Verlag, February 2004, Web. 22 May 2014

"Gesundheitsausgaben 2012 übersteigen 300 Milliarden." Statistisches Bundesamt Pressequelle, 07 April 2014, Web. 15 May 2014 https://www.destatis.de/DE/ZahlenFakten/GesellschaftStaat/Gesund heit/Gesundheitsausgabe $n /$ Aktuell.html

Green, David, et al. "Healthcare Systems: Ger-

many." Civitas, January 2013

http://www.civitas.org.uk/nhs/download/germ

any.pdf

Greß, Stefan, and Heinz Rothgang. „Finanzierungsreform der Krankenversicherung in Deutschland: Vorschläge für ein Maßnahmenbündel jenseits der Kopfpauschale." Friedrich Ebert Stiftung. Abtei- 
lung Wirtschafts-und Sozialpolitik der Friedrich-Ebert-Stiftung, December 2010.

Greß, Stefan, Simone Leiber, and Maral Manouguian. "Integration von privater und gesetzlicher Krankenversicherung vor dem Hintergrund internationaler Erfahrungen." WSI-Mitteilungen., July 2009

Iglehart, John. "The American Health Care System."New England Journal of Medicine.1999, 7, Jan.vol 340.1. 
ITA (International Trade Administration). "2012 Market Pro-

file:Europe."U.S. Dept. of Commerce.last accessed May $27^{\text {th }} 2014$.

$<$ http://travel.trade.gov/outreachpages/download_data_table/2012

_Europe_Market_Profile.p df $>$

JAMA. "The State of US Health, 1990-

2010".Journal of the American Medical Associa-

tion.2013;310(6) pp591-606.

$<$ http://jama.jamanetwork.com/article.aspx?articl

eid=1710486>

Kentucky (KY) Cabinet for Health and Human Services. "Analysis of the Affordable Care Act."KY Govenors Office. accessed May 27, 2014<http://governor.ky.gov/healthierky/Documents/MedicaidExpa nsionWhitePaper.pdf>

Kocher et al. "The Affordable Care Act and the Future of Clinical Medicine". Annals of Internal Medicine.2010 19, Oct. v153.8.

$<$ http://annals.org/article.aspx?articleid=746295\&issueno=8\&atab= 10>

Lauterbach, Karl. „Die Bürgerversicherung.“ Universität Köln, 2004.

Levy, Jena. "U.S. Uninsured Rate Drops to

13.4\%."Gallup.2014 5,

May.<http://www.gallup.com/poll/168821/un

insured-rate-drops.aspx>.

Lister, John. „Globalization and Health System Change.”

WHO Commission on Social Determinants of Health, uOttawa, 2008.

Nesti, G. et al. (2003), Providing integrated health and social care for older persons in Italy, Procare

(http://www.imsersomayores.csic.es/documentos/documentos/proca re-providingitaly01.pdf)

Niero, Mauro. Italy: Right Turn for the Welfare State. In Vic George and Peter Taylor-Gooby (ed.). European of Welfare Policy. Italy, Pg. 
$117-35$

http://books.google.de/books?id=amchxiHgM2wC\&pg=PA444\&lpg=P

A444\&dq=Mauro+Niero. + Ita-

ly:+Right+Turn+for+the+Welfare+State\&source=bl\&ots=SYA3A-

MN67\&sig=j77HbgCYdnPWBoR7xmMTWQDxCBc\&hl=de\&sa=X\&ei=YIO

IU_3gGtSS7AaMyYGYDw

\&ved=0CEgQ6AEwAw\#v=onepage \&q=Mauro\%20Niero.\%20ltaly\%3A\%

20Right\%20Turn\%20for\% 20the\%20Welfare\%20State\&f=false,

05/17/14

Nunley, Ryan. "Issues Facing America: Underinsured Pa-

tients."American Academy of Orthopedic Sugeons.2014

May.vol8.5.

$<$ http://www.aaos.org/news/aaosnow/mar08/reimburse

ment1.asp>.

Obermann, Konrad, et al. "The German Health Care System.

A Concise Overview" Der Ratgeberverlag, Hamburg 2013,

Web. 16 May 2014 http://miph.umm.uni-

heidel-

berg.de/miph/cms/upload/pdf/German_Healthcare_Syste

m_Extract.pdf 
"OECD Health Data 2013 - How does Germany Compare." OECD. June 2013. Web. 15 May 2014. http://www.oecd.org/els/healthsystems/Briefing-Note-GERMANY-2013.pdf

OTTI. "U.S. Citizen Travel to International Regions."U.S. Office of Travel and Tourism Industries.last accessed May $27^{\text {th }}$, 2014.http://travel.trade.gov/view/m-2012-0-001/index.html

"Otto von Bismarck." Social Security History. Social Security Administration, Web. 16 May 2014 http://www.ssa.gov/history/ottob.html

Porter, Michael E., and Clemens Guth. "Redefining German Health Care: Moving to a Value-based System". Springer, 2012.

Radich, Nicole A. "A Single Health Care System for a Reunified Germany." Martindale Center Lehigh University 1995, Web. 19 May 2014.

http://martindale.cc.lehigh.edu/sites/martindale.cc.lehigh.edu/fil es/radich.pdf

Reid, Thomas R. "The Healing of America: A Global Quest for Better, Cheaper, and Fairer Health Care". PBS Frontline, 15 April 2008, Web. 17 May 2014 http://www.pbs.org/wgbh/pages/frontline/sickaroundtheworld/count ries/models.html

Rettman, Andrew, 2014

http://euobserver.com/political/123010, 05/19/14 OECD (2012), Health at a Glance: Europe 2012, OECD Publishing. http://dx.doi.org/10.1787/9789264183896-en, 05/14/14

Rodrigues, João. „Die Private Krankenversicherung im Umbruch - Gesundheitsreform verschärft Prämienentwicklung. ", Barmer GEK, Web. 
17 May 2014 http://www.barmergek.de/barmer/web/Portale/Versicherte/Komponenten/gemeinsame_ _PDF__Dokumente/Publ ikationen/Rodrigues_08,property=Data.pdf

Roy, Avik. "New McKinsey Survey: 74\% of Obamacare Sign-ups Were Previously Insured."Forbes. 2014 10,May. http://www.forbes.com/sites/theapothecary/2014/05/10/newmckinsey-survey-74-of-obamacare-sign-ups-were-previously-insured/

Rusconi, Alessandra, 2006, Leaving the parental home in West-Germany and Italy, http://www.demogr.mpg.de/Papers/workshops/000906 _paper02.pdf, 05/20/14 Wallace, Lorraine S., "A View of Health Care Around the World." National Center of Biotechnology Information, January 2013. Web. 20 May 2013.

http://www.ncbi.nlm.nih.gov/pmc/articles/PMC359602 7/ 
"William Beveridge (1879 - 1963)." BBC Histo-

ry, Web. 19 May 2014

http://www.bbc.co.uk/history/historic_figures

/beveridge_william.shtml

„86 \% der Erwerbstätigen sind gesetzlich krankenversichert.“ Statistisches Bundesamt Pressequelle, 16 April 2013. Web. 14 May 2014 https://www.destatis.de/DE/PresseService/Presse/Pre 